\title{
THE CRUCIFORM COMMEDIA: AN ICONOGRAPHIC APPROACH
}

It is probably trite to note that in the Commedia Dante tells two stories, his own and that of Everyman. It is likely equally unnecessary to suggest that how these two stories interact, that is; how Dante ensures that his particular story and "Everyman's" story are reconciled, is a function of narrative structure. However, while it is frequently noted that, at points, the two stories intersect, ${ }^{1}$ I am unaware of any comprehensive attempt to plot out. pictorially or visually, the underlying narrative structure which effects this intersection. However, when we clo just that, when we illustrate visually the pilgrim's narrative ${ }^{2}$ progress, a surprisingly simple, yet remarkably elegant. substructure emerges. Transforming the Commedia's narrative structure into a pictorial representation reveals a cruciform image produced by two trajectories that intersect to form the ultimate icon of redemption. In this way, Dante creates a mental image in accordance with the conventions of medieval iconography and the medieval art of memory. ${ }^{3}$

This mental image gradually emerges if we step outside of the Commediais literal narrative and consider the work from a new perspective. When one visualizes the shape of the story which Dante tells, the "big picture" as it were, the Commedia takes on, if not an entirely new look, then one which is somewhat different from the impression engendered by traditional analysis. To effect this transformation from a literal narrative whose episodes we can, at times, visualize, to a mental image of the shape of the entire story, requires that we consider the cammin di nostra vita (Iif. 1, 1) as a horizontal linear progression. Mentally visualizing the road in this way is consistent with Dante's own view, expressed in Paradiso 30, that earthly time is linear as opposed to the circularity of eternity. ${ }^{+}$This linear horizontal progression. I term the "universal journey." This joumey is still Dante's story for Dante shares the universal experience of life, a passage through time and space from one point to another, with all men. In this journey he is not alone. However, in the middle of this road "Nel mezzo del cammin" Inf. 1, i) there is an interruption. Dante halts his horizontal progression and begins to move vertically. Dante's descent into Infermo, therefore, deviates from the collec- 
tive $\mathrm{e}^{5}$ and initiates his own distinctive journey.6 This vertical movement is what I term the "particular journey." The vertical nature of the particular journey is characterized by the ever-present ascent and descent pattern of the protagonist and the secondary characters. ${ }^{7}$ By locating the "up/down" paradigm, his particular story, within the journey of "our life," Dante is able to tell his own story in such a may as to ensure that it retains a universal significance. This structure is set out in a more visual manner in Figure 1.

The horizontal line depicted in Figure I. represents the universal journey. The vertical line represents the particular journey. The arrow pointing downwards represents Dante's descent into the Inferno. Within this first portion of the journey, Dante's encounters are marked by a lack of vision, by sterility and by futility, most notably in Farinata's inability to see the present, 8 Brunetto Latini's self-enforced sterility, ${ }^{9}$ and Francesca's hopeless wish that God might yet be a friend to her and to her suffering Paolo. ${ }^{10}$

To move away from this downward thrust, the pilgrim, Dante, must turn around and face the other way if he is to ascend to heaven, complete the cruciform and achieve redemption. At the bottom of Inferno then, he turns around $^{11}$ and starts an ascent towards the summit of Mount Purgatory. This takes him back up to the line that represents the universal journey. While the culmination of the purgatorial voyage in the verdant and lush Earthly Paradise contrasts the fertility of this route with that of the road to the pit of Hell, it is also one of the those points in the Commedia where critics frequently note an overlapping of the universal, or "exemplum," with Dante's own story. ${ }^{2}$ When we consider the pilgrim's journey from the perspective of the cruciform configuration, we understand why such overlap occurs. This is the point where Dante's particular journey rejoins the universal from which he diverted at the outset of Inferno.

Moreover, the cruciform configuration reveals that the first two portions of Dante's trek, the downward journey of Inferno and the ascendant voyage of Purgatorio, both of which take place below the horizontal line, are parallels of each other. Figure 1. is constructed in such a way that the precision of this parallelism is demonstrated visually. Starting at the point where Dante finds himself lost in the "selva oscura" (Inf. 1,2) and reading from left to right towards the nadir of Inferno, so that the reader follows Dante's journey to the pit of hell, we see that Dante starts this journey with the image of perilous water left behind. ${ }^{3}$ After making his way steadily downwards, the trip takes a 180-degree turn, so that while the reader continues to read from left to right, the rose window now lies to the right of the reader's field of vision. An image of the stars heralds the commencement of this new leg of the trip. ${ }^{14}$ 
Like the initial downward plunge, this second leg of the journey starts with an image of dangerous water left behind ${ }^{15}$ and its completion, or at least the commencement of yet another leg, is heralded by an image of the stars. ${ }^{16}$ That these two legs of Dante's journey are so similar begs the question - in what way are they dilferent? Textual clues tead to the conclusion evident in Figure 1.; that is, the first distinction between the two journeys is deictic. The first portion was directed away from heaven. depicted as the rose window in Figure 1., whereas the second leg is headed straght for it.

The corollary to the deictic distinction is also evident in the pictorial representation of Figure 1. which reveals that the first portion of the journey is truncated and is not part of a longer trajectory, as we see the purgatorial journey is. Unlike the self-contained downward thrust of the trip through Hell, the upward trek through Purgatory continues above the horizontal line. While all movement, action and discourse below the horizontal line can be characterized as earthly and temporal, only the trajectory that leads to the centre of Inferno can be said to he earthbound. The upward trajectory of Purgatorio contains a potential for ascent that its counterpoint does not. The distinction between the two journeys, therefore, is two-fold: the distinction between damnation and the chance for purgation lies both in direction and scope. ${ }^{17}$

The voyage away from God, the earthbound journey, is frequently associated with the loss of a Golden Age and yearning for past happiness, looking back rather than forward, being turned around and looking the wrong way. This mood of "paradise lost" permeates the Inferno. From Francesca's lament that there is nothing sadder in times of unhappiness than to remember happiness, 18 to the Old Man of Crete's tears for the corruption of society (Inf. 15), the denizen of Infemo invariably looks back rather than forward and, therefore, is similarly associated with being turned around and looking the wrong way. This imagery, which recalls the tragic fate of Lot's wife, or equally the pagan Orpheus, is firmly rooted in and reflects the essence of condemnation; it allows for no hope of redemption and thus renders looking forward pointless.

The tone changes considerably when Dante starts the arduous journey up through Purgatorio. We see the distinction first in the water imagery that opens the canticle. While it recalls the similar language that launched the infernal journey, the water imagery of Purgatorio 2 looks forward to "better waters" rather than dwelting on those from which the pilgrim has barely escaped. Throughout the purgatorial journey we will see other subtle instances of this deictic distinction. In Purgatorio 2, for example, upon the 
approach of the ship of souls, Dante looks first to Virgil for an explanation and then turns again to look at the ship only to find its brightness and mass magnified. ${ }^{19}$ Clearly, in Purgatory Virgil will not provide the only source of enlightenment as he did in Hell. Here in Purgatory, gazing back at the masters of the past for explanation is not sufficient. Here, enlightenment comes from other objects on which Dante will set his gaze and, more importantly, from looking forward rather than back. Thus, in Purgatorio 15, Virgil explains to Dante that if he were to turn his longings for material goods upu'ards, that is, towards God, that he would never experience the fear of losing them. ${ }^{20}$ And again, as Dante is about to enter the wall of fire, yet hesitates in fear, Virgil comforts him and advises the frightened pilgrim to turn with full assurance. ${ }^{21}$ The reorientation is completed in Purgatorio 30 when Beatrice's voice finally turns Dante around to look at her instead of back to see where Virgil has gone. ${ }^{22}$

Accordingly, the ascent to Paradiso is marked continually with references to looking up in order to move ever upwards. The most obvious indicator of this intentional verticality comes in Paradiso 22 where Dante finds himself directly above the earth in the sphere of the fixed stars. ${ }^{23}$ The point is reinforced in Paradiso 27 where Beatrice has Dante look down to see how far he has come. ${ }^{24}$ Since they are directly above the point from whence Dante has come, we see that vertical movement, not the passage of time, marks progression in the journey recorded in the Commedia.

It is important to remember, however, that the cruciform pattern is not used merely to plot out the spiritual significance of Hell, Purgatory and Paradise, much of which would have been understood by Dante's readers in any event. Rather, one must remember the cluality it encompasses. While the cruciform certainly charts Everyman's story, it uses events from Dante's particular life to clo so. Or put another way, the narrative framework created by the cruciform allows Dante to tell his own stories; his love story, the story of his development as a writer and the story of his political travails, in such a way that they take on universal significance. But there is still another function to the cruciform configuration. In addition to providing a narrative framework, the cruciform provides Dante with an interpretive or exegetical framework within which he can reconcile, evaluate and catalogue the events and evolution that comprise these stories. Within this multi-faceted framework, Dante can expose which of his thoughts, actions and sentiments were misdirected, which were correctly directed and, therefore, failed to reach their full potential and finally, which were destined for divinity. The cruciform matrix provides a common denominator, a format suitable for each of 
three seemingly disparate stories. As he carefully lays the events of each story upon the cross, Dante effects an overlapping and superimposition of the significance of each story and thereby proposes each as a figura of the others. For example, in the context of the love story, Dante uses the cruciform framework to situate each of the stages of his own experience of love. In the first part of the journey, in the Inferno, love is most often associated with eros, carnal love, love of the creation, not of the creator. Thus, we see Francesca, Semiramis and other examples of the sin of carnal love eternally damned. Similarly, in the first part of the journey, love is most often portrayed as illicit, sexual and conducive to jealousy, dissatisfaction and death and is often associated with courtly love and "fole amor." 25 Above all, it remains forever earthbound and narrow in scope. Within this context, we understand why the episode in which Beatrice descends into Limbo to speak to Virgil is painted in stilnovistic tones ${ }^{26}$ that recall the early love poetry of Dante and his contemporaries.

In Purgatorio, love is more closely associated with a classical, epic type of love, therefore associating the purgatorial journey with the Convivio and its increasing preoccupation with Virgil. For example, just as Dante is beginning to sense Beatrice's approach, he says, "conosco i segni dell'antica fiamma." (Purg. 30, 48) The words are taken almost verbatim from Virgil's Aeneid and, in the Commedia, are cited at the moment in which Virgil disappears, signaling that even epic love cannot reach heaven. ${ }^{27}$ However, Virgilian love is, nonetheless, distinguished from the epic lust of Ulysses that is forever relegated to the earthbound category. Aeneas, in the Commedia, is always characterized as pre-Christian as opposed to pagan or non-Christian. Virgil's treatment of love suggests a precursor to the tenets of Christian love, just as the Rome which Aeneas would found was a precursor to Christian Rome and in the same way that Aeneas's descent into the underworld was a precursor to Christ's descent. Ulysses, however, could not resist the very human temptation to seek forbidden knowledge and traveled away from the confines of divine ordination and was thrust forever into the realm of the earthbound with no possibility of ascent. Unlike Ulysses, Aeneas turned his back on the folly of erotic love and earthly pleasure and proceeded in the right direction.

Purgatorio also reflects the Convivio's dalliance with intellectual love; love of knowledge, or philosophy, and Dante's attempt to find a love distinct from the carnal, characterized in his own canon by the erotic love of the Vita muova. Nonetheless, it is only Christian love, the kind professed in the Commedia itself, that will take the lover above the horizontal line and into the realm of the celestial. Thus, in Paradiso we set yet another version of 
love; one which is familial, almost communal and the embodiment of knowledge at the same time. Here Beatrice calls Dante "frate" and Dante paints Beatrice as the giver of maternal love. ${ }^{28}$

The cruciform configuration is also used in a similar manner to chart Dante's intellectual progression, specifically that of his development as a writer. I have focused my examination on what I consider to be Dante's three autobiographical works, the Iita mova, the Comivio and the Divina Commedia, but it may well be that we can locate many of his other works within the great interpretive matrix that Dante creates with the cruciform. The poetry of courtly love first pervades the Inferno with Beatrice's and Virgil's exchange in Inferno 2 referred to above. Beatrice woos Virgil with her courtly style. She includes him in her vogue by calling him "cortese" (Inf. 2,58 ) and then reveals that she is moved by love. "Amor mi mosse," (Inf. 2, 72) she says and Virgil, in turn, calls her "donna." (Inf. 2, 76) The poetry raises its head again in Inferno 5, not just in Francesca's words but in her choice of reading material.29 The presence of Brunetto Latini and his Tresor ${ }^{30}$ makes it clear where Dante feels many of his literary contemporaries and near contemporaries are destined. The recuperative efforts of the Convivio ${ }^{31}$ and Dante's attempts to go beyond erotically motivated writing are on the right track but nonetheless fall short and are ultimately likened, in terms of usefulness, to the erotically charged literature represented by the Vita Nuova. Thus Beatrice's rebuke recalls elements of both the Vita Nuova and the Comivio and makes it clear that both literary pursuits and the "loves" they celebrate are essentially earthly and can go no further than Earthly Paradise. It is not surprising then that, in addition to the familiar echoes of the rita Nuova, ${ }^{32}$ we should also hear echoes of the Convivio throughout both the Inferno and the Purgatorio.33 It will only be with the writing of the Commedia and the love it exalts, that Dante will escape the bounds of earthly and temporal confines. Only the truly new kind of writing - new in Augustinian terms, as opposed to the illusory newness of the dolce stil nuovo - only the Commedia can take Dante to heaven, or in writer's terms, anctoritas. $3+^{3+}$

Thus, in Paradiso 4 Beatrice actually surpasses the philosophers featured in the Convivio for she can see the truths that they could not. ${ }^{35}$ In this portion of the journey, wisdom is shared and expanded beyond the confines of Dante's descent into the Inferno. The depiction of Beatrice as a philosopher fulfills the project first attempted within the Convitio; the reconciliation of sexual love with the love of philosophy. ${ }^{36}$ Here on the higher plane, love and knowledge become one and Beatrice becomes both. Beatrice's trans- 
formation into wisctom was foreshadowed as early as Pongatorio 30, 11 , where her arrival was heralded with words taken from the Song of Solomon, "Véni de Libano, sponsal meal, veni di Libano, veni" and in which, according to the Catholic interpretation, the bricle is the wisctom of God. (La I)irina Commedia 1955, 735) Moreover, the way Beatrice is dressed in Purgatorio 30, 31-33. ("sovrat candido rel cintal d'uliva/donna m'apparre, sotto verde manto vestita/ di color di fiamma viva.") $3^{3}$ also evolies theological wisclom. It is no coincidence, therefore, that Virgil disappears at this point, 38 not just because he belongs to the earthly but so that Dante can distinguish between pre-Christian and Christian wisdom. As Beatrice speaks the words of wisdom, we see that her words often echo Dante's earlier statements in other works. For example, when she explains that it is not just the natural influence of the hearens which affect one's destiny, but that each seed is directed to a determined end, ${ }^{39}$ Beatrice recalls what Dante suggested in Contivio IV', xxi, 7: "E però che... la disposizione del cielo puote essere buona, migliore e ottima la quale si varia per le costellazioni che continuamente si trasmutano, incontra che de l'umano seme e di queste vertudi più pur le men pural anima si produce." By assigning the role of teacher to Beatrice who is continually "provanclo e riprovando," (Par. 3, 3) Dante is able to attribute an expertise and a divine authority to his own knowledge without creating an appearance of being proud. Similarly, in Paradiso 29, "(1) Dante recalls Convivio III, vi, $4-5$ in which he earlier described angelic vision. ${ }^{41}$ Within the context of this new truth, Dante is able to absorb and reinterpret his earlier works, while, at the same time, reclassifying them. By extracting certain of his ideas and placing them within the interpretive matrix, Dante is able to suggest the relative merits of much of his earlier thinking. Unprepared to dispose of the entirety of his pre-Commedia work, Dante uses the revision, the new perspective of the Paradiso to correct the reader's vision. The salvation Dante accords the numerous ideas which appeared first in his early work and then again in the Paradiso, reveals a redeemable quality to much of Dante's thought but also underlines the necessity of divine enlightenment to revealing its previously hidden fundamental truth. Without such enlightenment, notwithstanding the potential of the Convivio's thought, its ideas will remain within the purview of the earthly and cannot lift the pilgrim above the horizontal line. Accordingly, while the limitations of reason left questions unanswered in the Purgatorio, ${ }^{42}$ in Paradiso these limitations are revealed as owing to the quality of reason, not to reason itself. Thus in Paradiso 2, Beatrice distinguishes between earthly and enlightened reason, ${ }^{+3}$ using the latter to "correct" Dante's moon theory. In P'aradiso 7, 10- 
12, "Io dubitava, e dicea 'Dille, dille!'/ fra me: 'dille' dicea, a la mia donna/ che mi disseta con le dolci stille," serves the same purpose with respect to the Vita nuovia and, indeed, with respect to Dante's adherence to the dolce stil nuovo. This explicit echo suggests that the "sweet" and "new" style of praise is appropriate only when it is directed towards the creator of the object of love and not towards the object of love alone.

In this portion of the matrix, Dante's wisdom emerges from, and surpasses the very individual circumstances that engendered it and, at the same time, coloured it. Its potential is fulfilled as Dante's thinking is first revised and then expanded beyond the confines of the literary attempts below the horizontal line. The fusion of the object of erotic love and the prey of Dante's intellectual pursuit creates a product that is greater than the sum of its parts. In combining two elements Dante has enhanced the meaning of both, so that the plot of his love story is revealed as a figura of his intellectual story and both become exegetical tools for interpreting the third narrative thread, his political story. ${ }^{44}$

The cruciform is essential to Dante's self-interpretation of his political activities and the concomitant evolution in his political thought as characterized in his early and intense involvement in the civic affairs of Florence. ${ }^{45}$ Thus, the descent into Hell can be said to represent the blind, shortsighted focus of local politics embodied by the Florence of Dante's time. Although the Inferno is clearly removed geographically from the world of the living, it is clear that it is not completely detached from it either. Just as the bodies of the damned have been transformed by Dante's strategy of contrapasso, so here the physical city of Florence, while transformed, is still recognizable. Though its baptistery and churches are gone and in their places are graveyards and woods of suicides, its gates and walls remain as a reminder of the city's power to exclude and shut out. The pilgrim and the reader are aware almost from the start of the descent that Dante's first destination is associated, at least in some way, with Florence. Throughout the Inferno we encounter Florentines; Ciacco in Inferno 6, Florence's spendthrifts and misers in the fourth circle and, of course, Filippo Argenti in Inferno 8. ${ }^{46}$

But perhaps the character who most represents the downward myopic focus of Florence is Farinata degli Uberti. (Inferno 10) Farinata epitomizes Dante's vision of Florence as a political Hell. Certainly not the only character to provide political commentary, Farinata is the anthropomorphosis of the essence of Florence and its sins. While other characters tell of statues to the gods of war, expanding city limits and increasing rivalry amidst a growing population, ${ }^{47}$ it is in Farinata that these are all fused into a single char- 
acteristic, shortsighted pricke. Farinata's epicureanism is revealed as merely one element of a greater caustic feature. The pride of Florence is what has made it blind to the destruction and trauma it has wrought but it is also symptomatic of its myopic view of the world. This myopia is the cquintessence of political thought that concentrates on the city-state and local concerns. Farinata's apparent oblivion to his surroundings and his inability to see the present exclaims this loud and clear and prefigures the fate of those who similarly limit their vision.

In his encounter with Farinata, Dante, to a certain extent, shares this pride. Dante, the pilgrim, smugly tells Farinata of the ultimate defeat of the Ghibellines, thus taking part in the political tit-for-tat that has become the bane of Florence. How do we explain this? The answer lies in remembering that Dante was a Florentine. After his exile he did not simply wash his laands and bid the city good riddance. Rather, Dante spent much of his time early in his exile trying to regain entry to Florence and consorting with other exiles. Notwithstanding the bitterness he bore Florence, Dante still wished to return there. In the depths of the Inferno, Dante is still mired in his Florentinism. He has not yet turned his back on Florence and looked for a new direction. Dante, the author, has drawn Dante, the pilgrim, as the figural representation of his own political heliaviour. It is for this reason then that Dante enters into the debate with Farinata. The issue of who will ultimately hold the reigns of power in Florence is the essence of the local and earthbound character of Dante's early political thought. It reflects Dante's early activities within the city-state and reflects the prevailing Florentine opinion that Florence was subject to no power but its own. Dante's discussion with Farinata and where he locates the conversation reveals the value Dante now assigns to such debates. Dante's descent into Hell, therefore, figures not only his exile but the early steps in his own political journey. And both lead downwards as the literal narrative takes the pilgrim ever closer to the nadir of Hell and the murder of a Roman Emperor. ${ }^{+8}$ The message is relatively simple to glean; preoccupation with the city-state results in betrayal of the Empire as Dante himself sets out in his sixth epistle. ${ }^{9}$ More importantly, while the juxtaposition of this crime with Judas's betrayal of Christ alerts us to another layer of meaning, it also reveals Dante's cataloguing project. Both crimes are assigned the same value, characteristics and implications. The preoccupation with the city-state, its resulting ignorance and ultimate betrayal of the empire shares meaning and effect with the betrayal of Christ: betrayal of the empire is the political equivalent of the betrayal of the son of God. Both constitute a laying to waste not only of at divine gift, 
but of a means of salvation.

The ascent through Purgatory attempts to remedy the political myopia of the Inferno and in this sense, it also resituates the Contivio. While many of the thoughts expressed in the Comivio will ultimately be revealed as earthly, its recuperative efforts, especially in terms of Dante's riem on the issue of Empire, are shown to have been right-minded even if they fell somewhat short of the riews expressed in the Commedia. ${ }^{50}$ Whereas, in Book $\mathrm{IV}^{\top}$ of the Comlinio, Dante has turned his mind to assessing the purposes and benefits of the Empire, he does not go so far as to suggest it as an iter to salvation. The Empire of the Convivio remains firmly rooted in the earthly. That is, while Dante recognizes a divine quality to the establishment of Rome, ${ }^{51}$ he suggests a limitation to its powers that is also divinely ordained. 52 While recognizing a certain divinity in the inception of the Empire, the Contivio is not able to make the more explicit connection between the Empire and salvation that the Commedia cloes. Moreover, the more Dante's focus shifts to Virgil and the Aeneid in Book IV of the Convilio, the more Dante fuses his vision of Rome to a vision of Empire that, like its chronicler, Virgil, is ultimately limited to the earthly. As long as he continues to look backwards to Rome's founding, Dante cannot look forward to where the Empire leads. It is no wonder then that Dante left the Convivio unfinished; it could go only so far. The cruciform pattern, again, figures this limitation but reveals that Dante was on the right track. In order to get to Heaven, one must first get to Rome, or as Dante represents it, the garden of Earthly Paradise. Just as Florence was figured as Hell, in the Commedia. Rome, through a series of allusions, is figured as the garden of Earthly Paradise. 53 Since Dante also depicts Heavenly Paradise as a garden, this depiction also forges a figural affinity between Rome and Heaven. The connection between Rome and Heaven is made explicit in Purgatorio 32 with the reference to "that Rome" where Christ is a Roman. ${ }^{54}$ Thus we move from a city that tries to stand alone (Florence) to a city whose fame comes from being a component (albeit a ruling one) in a greater structure. If preoccupation with the city as a citystate will take us down to the core of Hell, preoccupation with the city as a smaller component in a larger entity, that is, as the cornerstone of an Empire, can help us get back up to the point from which we started. If the city provides the road to Hell, then the Empire provides the ticket to Heaven.

Therefore, the restoration of Rome as the earthly empire is not an end in and of itself. It is part of a greater conquest that will bring about the heavenly kingdom, which in the Paradiso, is associated with Jerusalem. In the Commedia then, the road to Rome and the road to Jerusalem lie along the 
same trajectory. The journey to one is a step in the journey to the next. just as the purgatorial journey of figure $I$. is contained within the larger trajectory leading to Jerusalem. 55 Therefore, the language of Purgatorio recalls pilgrimages to both cities, first with the song of the new atrivals, "In exitu Isracl de Acgypto" (Purg. 2, 16 ) and then with the reminder that "Tiber"s watter" is the source of the journey to Purgattory. ${ }^{50}$ 'The potentiality of the journey to Rome is consistent, therefore, with the potentiality of the second leg of Dante's journey. Being a smaller part of a greater trajectory, the journey to Rome is not plagued by the sterility and stunted potential of the road to Hell. In Pargatorio and Paradiso, as in the Infermo, Dante continues to meet Florentines but now they bear differing associations. Cacciaguida, in contrast to Farinata, is not tied to the Florence that Dante associates with Hell. He recalls Florence's glorious past and, like Dante, laments the city's fall into licentiousness. However, rather than continue stubbornly to attach significance to the differences which have resulted in petty local turf wars. Cacciaguida tells of his death on a crusade, on his way to Jerusalem to fight a greater battle. ${ }^{5-}$ Cacciaguida's fight is one in which all Christendom is united against a common enemy. It is not local in nature. It is not an exclusively Florentine issue. This echoes Dante's sentiment with respect to the papal wars ${ }^{8} 8$ in contrast to his view of the Crusades and marks a clearly expanded significance to Jerusalem beyond its physical existence.

Cacciaguida's episode does more than illustrate Dante's political evolution. Structurally, the episode creates an immediate backward glance to the other Florentine who predicted Dante's exile, Farinata. Cacciaguida, like Farinata, is able to recite the destinies and inheritance of Florence's leading families. Cacciaguida's perspective, however, is broader than Farinata's and contains an interpretive function as he cleduces that it was pride that brought about the downfall of many of these once great clans. Cacciaguida follows his remarks about the pride of families ${ }^{59}$ with one about the pride of Florence 60 demonstrating, again, how closely Dante links the city with its citizens and how close a resemblance he sees between civic and familial pride. The wwo episodes help interpret each other in that, similarities in the episodes highlight the contrasts. Thus, we see that Florentines are not inevitalbly damned but rather, that it is a question of perspective or focus and clirection that determines their fate. Florentines and presumably. Florence, can be salved if they look beyond themselves, just as lovers can be saved if they look beyond the object of their love. The episodes, therefore, also reinforce the narrative structure of the Commedia in their conformity to the parallel, or perhaps, more accurately, opposing trajectories of the cruciform narrative in 
which the journey below the horizontal line is the antithesis of the journey above the horizonal line.

Thus we see that the cruciform structure provides an exegetical tool through which Dante can make sense of otherwise apparently disconnected aspects of his life. But there is another aspect to the cruciform which such an examination involves; that is, its role in the mnemonic function of the Commedia. Francis Yates notes that some have interpreted the Commedia as following the mnemonic principles of the time. ${ }^{61}$ Indeed we know that Brunetto Latini, Dante's tutor, was among those involved in translating portions of Ad Herrenium (Yates $88 \mathrm{n} .21$ ) so it is not unlikely that Dante would have been aware of the prevailing memory conventions and their classical origins. However, the mnemonic approach to the Commedia has tended, thus far, to look at the images that Dante creates with the literal text, for example, the circles of Hell, the spheres of the planets etc. It does not consider the possibility of an underlying intertextual mnemonic image that engenders the Commedia's uniquely deictic narrative structure and the resultant exegetical matrix. Given Dante's proclivity to polysemy, it appears quite plausible that he would not limit the inclusion of a mnemonic function to a single layer of meaning. I believe that there is good evidence on which to conclude that Dante has included within the text of the Commedia an additional mnemonic layer intended to conform to the then current conventions of the art of memory. It would appear quite plausible and, I would submit, highly probable that Dante intended that the reacler extract, from within the text, a "mental cathedral," a building that was not only a common edifice in medieval memory exercises but a building that, in the Middle Ages, was most often laid out on a cruciform pattern.

Within the cathedral, the nave can lead outside or to the altar, depending upon the direction in which one walks. Similarly, the transept and the rood screen create a barrier between the congregation, the ordinary earthly lives and the sanctuary in which the initiates and the clergy are situated. Finally, the rose window at the end of the church rising beyond the altar represents the eastern light source, illumination for the Church. It has been suggested that the source for Dante's celestial rose may have been the rose windows found in the medieval churches. ${ }^{62}$ Indeed, this theory is highly tenable, especially if one is prepared to go even further and suggest that the source for the entire layout of the intertextual structure was the church in which such windows were found and that Dante's use of the image was intended to make the mind picture even more explicit.

While the foregoing provides a mere starting point in assessing the extent 
to which an intertextual structure informs the exegetical structure and mnemonic functions of the Commedia, it nonetheless suggests an atspect to the Commedia consistent with what is eminently evident on the textual level. Considering the Commedia in this way; that is, considering that it creates a cruciform shape that the reader is intended to visualize mentally, furnishes the Commedia with another dimension and a fullness that was otherwise lacking. The cruciform pattern creates an internal interpretive and cataloguing device through which Dante can ascribe meaning and value not only to his own events but to those of world history and explain why the same act may not always draw the same consequences. The end to which a particular act is directed, the focus or intent of the sinner, the direction in which one travels or looks will determine whether one will find oneself on the way out of the Christian fellowship or on the way to communion at the altar. The direction determines whether the traveler's back will be turned away from the celestial rose or whether the pilgrim can walk towards it, to be blinded not by the lack of light but by its abundance. At the same time, the cruciform provides a mental picture of the most fundamental Christian symbol. With the creation of a poem which makes the sign of the cross, Dante leaves no doubt as to the poem's significance or its divine authority. The Commedia is not only about redemption, it is the means by which Dante himself is redeemed.

\section{State University of Neu' York at Buffalo}

\section{NOTES}

1 The point at which most critics note an intersection of "Everyman's" story, or as I term it, the "universal," with Dante's own, or again, as I term it, the "particular," is when Beatrice appears to Dante at the pinnacle of Mount Purgatory. Natalino Sapegno. for example, sees Beatrice and Dante as real creatures tied to "una cronaca di esperienze intellettuali e affettive personalissime." (La Divina Commedia 1955, 736) At the same time. he suggests that they are "figure di una realtà soprasensibile, partecipi di un'arcana vicenda, investite di un peso esemplare." He characterizes theirs as a story of an earthly love which is suddenly transferred to the plane of a universal and extratemporal lesson. ( $\mathrm{La}$ Divina Commedia 1955. 736) Theodolinda Barolini notes the Commedia's "intersecting of the universal with the singular" which she says is "never more on display than in these cantos, where the Pilgrim's encounter with Beatrice and personal confession are literally enfolded by universal history." (158) I will discuss below why I believe such intersection is especially accute at this point.

2 I emphasize the word narrative to distinguish my efforts from those efforts of those who have attempted to chart the physical or literal journey of the pilgrim by composing great charts of the various places of hell, purgatory and heaven. For an in-depth treatment 
of the many efforts at mapping Dante's three realms see Kleiner, John. Mismapping the Lndemerld. Daring and Enor in Dante's 'Comedy'. Stanford: Stanford U.P., 1994.

3 For a definitive treatment with respect to the art of mnemonics in the Middle Ages see Yates, Frances. The Art of Memory. Chicago: University of Chicago Press, 1966. Yates discusses, at length, the evolution of mnemonic practices in the Middle Ages; from the adaptation of the methods ensconced in the classical Latin works, to the visual application of such techniques in the works of medieval artists. Yates focuses on the teclunique in which memories are stored and recalled through the creation of a mental picture of a plyysical location - often a cathedral or a palace - into which mental inuages of the ideas sought to be remembered are placed.

${ }^{+}$Dante presents a river of light, a horizontal flow which is tranformed in his eyes, into a circular shape, once he has drunk from it ("e sí come di lei bevre la gronda/ cle le palpebre mie. cosí mi parve/ di sua lunghezza divenuta tonda." Par. 30, 88-90) thereby opposing the linearity of mortal vision with the circularity of the eternal.

5 Dante makes it clear that the road he travels, the life he has been given, is one shared by all, for he calls it "our life." ("Nel mezzo del cammin di nostra vita" Inf. 1, i; empluasis mine.)

${ }^{6}$ Again, Dante's choice of voice, the switch from the first person plural to the first person singular, signals a shift in action, a change in focus from the collective to the individual. ("mi ritrovai per una selva oscura" Inf. 1, 2; emplasis mine.)

- Amilcare Iannucci has noted, for example, the overwhelming presence of a vertical pattern, specifically that of descent, in Beatrice's role. (Forma ed etrento nella Divina Commedia 65)

8 "Quando s'appressano o son, tutto è vano' nostro intelletto; e s'altri non ci apporta,/ nulla sapem di rostro stato umano." (Inf. 10, 103-105) That this blindness is intended to synecdochically represent Florentine blindness in general is made clear when, several canti later, Brunetto Latini recalls Farinata and the proverbial Florentine blindness in the same warning to Dante. In Infemo 15, 67. Brunetto recalls an adage which calls Florentines blind ("Vecchia fama nel mondo li chiama orbi") and then in line 9+ recalls Farinata through an allusion to his prophecy of Dante's exile. ("Non è nuova a li orecchi miei tal arra") Natalino Sapegno provides possible origins of the proverb whose origin is by no means certain. (La Divina Commedia 1985, 175)

9 Brunetto Latini is placed in Inferno 15 in the third "girone" or round, of the seventh circle, amongst those violent against nature, specifically, the sodomites whose sexual practices riould not result in reproduction.

10 Francesca's awareness of the futility of the desire is revealed in her use of the subjunctive: "se fosse anico il re de l'universo, noi pregheremmo lui de la tua pace." (Inff. 5. 91-92)

11 The descent out of hell is marked by an initially confusing passage in which virgil and Dante climb along Lucifer's matted coat in a downwards direction. ("appigliò sé a le vellute coste: di vello in vello giú discese poscia trá 'l folto pelo e le gelate croste" Inf. 3t, 73-75) Virgil turns (and Dante follows) where the monster's thigh meets his haunch and starts climbing again, in a direction that Dante thinks will bring them back towards Hell. Somerhat confused (as he clearly guessed the reader might be) Dante asks for an explanation ("at trarmi d'erro un poco mi favella:/ ov'è la ghiaccia? e questi com'è fitto/ sí sottosopra? e come, in si poc'ora, da sera a mane ha fatto il sol tragitto?" Inf. 3+, 102-105) and Virgil explains to Dante that they turned at the centre point of gravity. ("ov'io mi presi al pel clel vermo reo che 'l mondo fora./ Di là fosti cotanto quant'io scesi;/ quand 'iomi volsi, tu passasti 1 punto/ al qual si traggon d'ogne parte i pesi." Inf. 34, 107-110) The confusion that might arise from an initial reading is easily allayed when one imagines Virgil and Dante descending into a splıere, feet first, as if going clown a set of stairs. At 
the centre of the spluere, they turn upside-down and start an ascent to the other side of the sphere, to the point opposite the initial departure point.

12 see note 1 aloreve.

1.3 "E come quei che con lena affannata uscito fuor del pelago a la rival si volge a lacequa perigliosa e guata, cosí l'animo mio, clancor fuggiva. si volse a retro a rimirar fo passo che non lasciò già mai persona viva." ( $m f .1,22-27$ )

1.4 "salimmo sú, el primo é io secondo, tanto ch"ï" vidi de le cose helle che porta "l ciel, per un pertugio tondo; e quindi uscimmo a riveder le stelle." (IIf. 3-1, 136-139)

15 "Per correr miglior acque alza le vele/ omai la navicella del mio ingegno, che lascia clietro a sé sí crudele;" (Purg. 1, 1-3)

16 "Io ritornai da la santissima onda rifatto sí come pinate novelle/ rinovellate di novella froncla, puro e disposto a salire a le stelle." (Purg. 33, 142-145)

$1^{-}$The importance of looking in the right direction is omnipresent in the Commedia. Lina Bolzoni ("Costruire immagini" 64-65) notes the multitude of examples in which the "guardar fisso" figures in Purgatorio and Paradiso. Nowhere is its importance, however, made more clear than in Paradiso 31 where St. Bernard tells the pilgrim. "Figliuol di grazia, quest-esser giocondo"/ cominciò elli "non ti sarà noto,/ tenendo li occhi pur qua giú al fondo:/ ma guarda i cerchi infino al piú remoto/ tanto che veggi secter la regina cui questo regno è suddito e devoto." (112-117)

18 "Nessun maggior dolore/ che ricordarsi del tempo felice; ne la miseria." (Inf. 5, 121123)

19 "Dal qual com"io un poco ebbi ritratto l'occhio per domandar lo duca mio. rividil piú lucente e maggior fatto." (Purg. 2, 19-21)

20 "ma se l'amor de la spera suprema/torcesse in suso il desiderio vostro,/ non vi sarebbe al petto quella tema;" (Purg. 15, 52-54)

21 "Pon giú omai, pon giú ogni temenza:/ volgiti in qua e vieni: entra sicuro!" (Purg. 27, 31-32)

22 "quando mi volsi al suon del nome mio,/ che di necessità qui si registra,/ vidi la donna che pria mappariò velata sotto l'angelica festa,/ drizzar li occhi ver me di qua dal rio." (Purg. 30, 61-65)

23 "Col viso ritornai per tutte quante/ le sette spere, e vidi questo globo/ tal, chi io sorrisi del suo vil sembiante;" (Par. 22, 132-135)

2.4 "Onde la donna, che mi vide assolto de l'attendere in sù, mi disse: "Adima il viso, e guarda come tu se' volto." (Par. 27, 76-78)

25 For a broader examination of the notion of 'fole amor' in the Inferno, and in particular, in Inferno 5, see lannucci, Amilcare A. "Forbidden Love: Metaphor and History (Inferno 5)."

26 In Infermo 2, 76 Virgil calls Beatrice "donna di virtù..." which Sapegno notes, recalls l'ita nuota 10, 2 where Beatrice is described as "distruggitrice di tutti i vizi e regina delle virtudi." (La Divina Commedia 1985 24) In particular, when Beatrice tells Virgil she will speak kindly of him to her Lord ("Quando sarò dinanzi al signor mio, / di te loderò sov'ente a lui." Inf. 2, 73-74), we are reminded of the hope of recompense for one's adoration central to the doctrine of courtly love.

27 "agnosco veteris vestigia flammae..." Aen. IV. 23

28 Beatrice ceased to be the object of sexual love as early as Purgatorio 33, 23 where she referred to Dante as "frate." Indeed, by Paradiso 7 she is calling him "frate" $(58,130)$ with increasing frequency. In keeping with this familial nature of love, Dante has also been painting Beatrice as the giver of matemal love. In Purgatorio 33, Dante describes Beatrice in terms which describe her as the essence of motherly love, Mary. ("E Beatrice, sospirosa e pia, ascoltava sí latta, che poco piú a la croce si cambiò Maria." 4-6) She is similarly characterized in Paradiso 1. 100; "Ond'ella, appreso d'un sospiro, li occhi driz- 
zò ver'me con quel sembiante/ che madre fa sovra figlia deliro." In Paradiso 22, 2-6 Dante turns to Beatrice "come parvol che ricorre/ sempre colà dove piú si confida" and Beatrice is described "come madre che socorre/ subito al figlio palido e anelo/ con la sua voce, che 'l suol ben disporre." When, in Paradiso 23, Beatrice cedes to Mary, it is a simple task to transfer the language of mother and child used to describe the relationship between Beatrice and Dante, to describe the relationship between Mary and Dante; "E come fantolin che 'nver la mamma/ tende le braccia, poi che 'l latte prese,/ per l'animo che 'nfin di fuor s'infiamma." (121)

The contrast between the erotic love of the Inferno and that of the Paradiso is also implied in Dante's description of Mary in Paradiso 23, 73: "Quivi è la rosa in che 'l verbo divino/ carne si fece." Mary is metaphorically a rose but, as Amilcare Iannucci points out, she is associated with a white rose as opposed to the red rose of earthly courtly love. "However, Dante's "candida rosa" also, obviously, stands for divine love in contrast (and the cultural reference is certainly willed) to the red rose of the Roman de la rose, a symbol of earthly love." ("Paradiso XXXI" 473)

29 Francesca tells Dante that she and Paolo were led to adultery while reading "di Lancialotto." (Inf. 5, 128) Natalino Sapegno notes that the reference is likely to the story of Lancelot du Lac, a French romance, known to Dante either in its original or in one of the many translations. (La Divina Commedia1985, 65 n. 128) The romance is rooted firmly in the French tradition of courtly love. As Urban Holmes points out, the great prose "Lancelot" of the Thirteenth Century Vulgate Cycle mentioned in Inferno V was adapted from Chrétien de Troyes's Chevalier de la Charette or Lancelot. Chrétien de Troyes undertook the work at the request of Marie de Champagne whose court like that of her mother, Eleanor of Aquitaine, was famous and lively circles of courtly love literature. (37-38)

30 In Inferno 15, Brunetto Latini, placed amongst the violent against nature, in his parting words to Dante, says to remember his Liure don Tresor, through which Brunetto will live on. ("sieti raccomandato il mio Tesoro,/ nel quale io vivo ancora, e piú non chieggio." 119-120.) While Brunetto implies that his writing will take the place of an eternal soul, the fact remains that Brunetto himself in placed in Hell. Writing cannot replace the emptiness of a soul nor can it bring redemption. Indeed, it is only through its inclusion in the Christian work of Dante that the Tresoir has gained a species of literary redemption or, at least, literary longevity.

31 'E se nellla presente opera, la quale è Convito nominata e vo' che sia, più virilmente si tratasse che nella Vita Nuova, non intendo però a quella in parte alcuna derogare, ma maggiormente giovare per questa quella; veggendo siccome ragionevolmente quella fervida e passionata, questa temperata e virile essere conviene." (Conv. I, i)

32 In Purgatorio 29 Dante describes the holy procession coming towards him as "sí com'elli eran cadelabri apprese/ e ne le voci del cantare 'osanna"' (49-50) reminding the reader of the ending of the Vita Nirova. As Robert Hollander notes, in Purgatory 30 Beatrice's angelic choir seems to pick up where it left off in the Vita Nuova. (55) Natalino Sapegno also points out that the arrival of Beatrice in Purgatorio 30, 28-33 recalls the imagery used to describe her in the Vita Niova 23, 7, 25; " "e paremi vedere moltitudine d'angeli li quali tornassero in suso ed aveano dinanzi da loro una nebuletta bianchissima. A me parea che questi angeli cantassero gloriosamente, e le parole del loro canto mi parea udire che facessero queste: Osanna in excelsis; e altro non mi parea udire." (La Divina Commedia 1955 737) The closer Beatrice comes to the pilgrim, the further back in time the reader is transported, so that when we finally see her clothing in lines 23 to 33 , as Sapegno says, we can't help but be reminded of the "vestito rosso 'sanguigno' e il bianco" already worn by Beatrice in the Vita Nuor'a. (La Dit'ina Commedia 1955736,737 ) But we continue to slide back in time so that in the same canto ("Prima ch'io fuor di puerizia fosse," Purg. 30, 42) we are brought back precisely to that moment in the Vita muov a 
when Dante first met Beatrice. ("Flla era in questa vita già stata tanto, che ne lo suo tempo) lo cielo stellato era mosso verso la parte d'oriente de lo doclici parte l'una deun grado, si che (quasi del principio del suo anno nono apparve a me, ed io la vicli, quasi de la fine det mio nono." Iita mola 2, 2) Most importantly, the direct use of the words "vita nova" draws the reader's attention back to the earlier work. "(questi fu tal ne la sua vita nova virtualmente, chogne abito clestro fatto averebhe in lui mirabil prova." Purg. 30, 115-117) Eventually, Beatrice's reference to Dante's wavering ficlelity "Alcun tempo il sostenni col mio volto:/ mostrando li occhi giovanetti a lui, meco il menava in dritta parte volto" P'urg. 30, 120) not only recalls the lita mora but also reminds us of the struggle to which Dante refers in Comitio II, ii. ("Ma perocche non subitamente nasce amore e lassi grande c viene perfetto, ma vuole alcuno tempo e nutrimento di pensieri contrarii che lo mpediscono, convenne, prima che questo nuovo amore fosse, molta battaglia intra "l pensiero del suo nutrimento e quello che gli era contrario, il quale per quella gloriosa Beatrice tenea ancora la rocca della mia mente.") The reference effectively draw's an affinity hetween the two morks and thereby exposes their mutual weaknesses.

33 Not only does the "via smarrita" in Infermo 1 locate the work thematically but it echoes language used throughout the Convizio. (Convivio IV, i, 9 "proposi di gridare a la gente che per mal cammino anclavano, acciò che per diritto calle si dirizzassero;" IV, xii, 19 "lo buono camminatore giugne a termine e a posa; lo erroneo mai non l'aggiugne;" IV, xvi, 10 "E per lo cammino dritto è cla vedere;" IV, xxii, 6 "cosi questi umani appetiti per diversi calli dal principio se ne vanno, e uno solo calle è quello che noi mena a la nostra pace;" IV, xxiv, 12 "che entra ne la selva erronea di questa vita, non saprebbe tenere lo buono cammino;" IV, xxriii, 2 "l'altra si è, che ella benedice lo cammino che ha fatto.") Furthermore, the image of "selva oscura" which so marks Inferno I cannot help but recall Cominio 1V, xxiv, 12 and "la selva erronea di questa vita" and with it Dante's preCommedia attempt to redeem those who had lost their way, philosophically and politically.

34 For Dante, as well as for his contemporaries, there was a distinction between a mere writer and an author or an auctor. The latter carried with it the stamp of historicity and was more closely associated with the modern English term "authority." Dante's definitive statement on the issue of auctoritas, that an autore is one who is not only to be believed but obeyed (Comizio IV, vi; 5 "E cosi 'autore,' quinci derivato, si prende per ogni persona degna d'essere creduta e obedita."), is clear evidence of the esteem in which he held such status.

35 Charles Singleton suggests that Dante's portrayal of Beatrice reflects Thomist thought in that her divine knowledge not only contains philosophy but perfects and, therefore, transcends it. (13i) Amilcare lannucci has also noted that Beatrice in Paradiso $\&$ often echoes St. Thomas, (Forma ed elento nella Dirma Commedia 87) Theodolinda Barolini suggests that Beatrice, at times, is also the spokesperson for St. Augustine. (102)

36 Bruno Nardi sees the pursuit of knowledge in the Conzivio as one which is expressed in philosophical terms. In the Commedia, however, he considers that the reconciliation takes the form more of that expressed by Gilson in his writings on Saint Bernard and courtly love.

37 Natalino Sapegno (La Diz'ina Commedia 1955, 737) cites Landino who notes, " i colori del velo, del manto, della veste alludono alla fede, alla speranza, alla carita: le quati tre virtù sono solo della Teologia, e per questo sono detto teologiche." The olive wreath may signify. "la pace, la quale è nell'animo quando si è adornato da fede; e la vittoria imperò che niuna cosa li è poi dura a credere o intendere ce operare: ce la sapienza imperò che l'ulivo è consecrato a Pallade [cfr. il V. 68], che e la dia de la sapienza, la quale è corona de la santa teologia."

38 Purgatorio 30, 49, according to Natalino Sapegno. is used to denote that moral phi- 
losophy cedes to the supernatural and to the divine, as a more noble science and one that is worthy of her. (La Divina Commedia 1955, 738)

39 "Non pur per ovra delle rote magna/ che drizzan ciascun seme ad alcune fine/ secondo che le stelle son compagne" (Par: 30, 109-111)

40 "Queste sustanze, poi che fur gioconde/ de la faccia di Dio, non volser riso/ da essa, da cui nulla si nasconde:/ però non hanno vedere interciso'da nono obietto, e però non bisogna rememorar per concetto diviso." (Par: 29, 76-81)

41 "Poi quando dico: Ogni Inteletto di là su la mira, commendo lei. non avendo rispetto ad altra cosa. E dico che le intelligenze del cielo la mirano, e che la gente di qua giù gentile pensano di costei, quando più hanno di quello che loro diletta. E qui è da sapere che ciascuno Inteletto di sopra, secondo ch'è scritto nel libro de la cagioni, conosce quello che è sopra sé e quello che è sotto sé. Conosce adunque Iddio sì come sua cagione, conosce quello che è sotto sé sì come suo effetto, e però che Dio è universalissima cagione di tutte le cose, conoscendo lui, tutte le cose conosce in sé, secondo lo modo de la Intelligenza. Per che tutte le Intelligenze conoscono la forma umana, in quanto ella è per intenzione regolata ne la divina mente; e massimamente conoscono quella le intelligenze motrici, però che sono spezialissime cagioni di quella perfettissima, tutto quanto esser puote, si come loro regola ed essemplo."

42 "Quanto ragion qui vede/ dir ti poss"io; da incli in là taspetta/ pur a Beatrice. chiopra di fede." (Purg. 18, 46-48)

43 "Ella sorrise alquanto, e poi "S'elli erra/ l'oppinion" mi disse "de' mortali/ dove chiave di senso non diserra,/ certo non ti dovrien punger le strali/ d'ammirazione omai, poi dietro ai sensi/ vedi che la ragione ha corti lali." (Par: 2, 52-57)

${ }^{4}$ Amilcare Iannucci has identified three separate plot lines contained within the Commedia; the story of Dante's love for Beatrice, the story of Dante's political vicissitudes and the story of Dante's development as a writer. ("Paradiso XXXI" 470 )

${ }^{45}$ See Piattoli, R. Codice diplomatico dantesco. Florence, 1950. for reproductions of the numerous documents which attest to Dante's involvement in Florentine civic affairs. See also Petrocchi, Giorgio. Biografia. Attività politica e letterearie. Vol. 6 of Enciclopedia Dantesca. Rome, 1978. 1-53 for a more detailed study of Dante's early political life, ambitions and philosophy.

46 Joan Ferrante offers an extensive examination of the similarities between medieval Florence and the City of Dis, enumerating the "several hints within the Comedy" that Dante equates Florence with Hell. (67) Amilcare Iannucci has also noticed this connection, pointing out that, in his opinion, "The Florentine suicide at the end of the canto (Inf. 13, 130-151) represents figuratively the whole city." ("Paradiso XXXI" 478) Perhaps the meaning of Hell in the Commedia was best expressed by Alan Charity who saw the issue in terms of Erich Auerbach's theory of figura and fulfilment and concluded that Hell is fulfilled in Florence. (245)

${ }^{7}$ In Paradiso 16, Cacciaguida tells Dante of the Florence "of old," referring to the initial walls of the original Roman encampment which marked the first borders of the city; the small but pure Florentine population and the mutilated statue of Mars which once stood at the head of the Ponte Vecchio.

48 "Quell'anima là sú c'ha maggior pena"/ disse 'l maestro, "è Giuda Scariotto,/ che "l capo ha dentro e fuor le gambe mena./ De li altri due c'hanno il capo di sotto,/ quel che pende dal nero ceffo è Bruto:/ vedi come si storce, e non fa motto; e l'altro è Cassio che par sí membruto." (Inf. 3t, 61-69)

4) Written March 31, 1311 to the Florentines: "Quid fatua tali opinione submota, tamquam alteri Babylonii, pium deserentes imperium nova regna tentatis, ut alia sit florentina civilitas, alia sit romana?" ("Wherefore, then, stirring up so vain a thought as this, do ye, a second race of Babylonians, desert the compassionate empire and seek to estab- 
lish new kingdoms, making the civic life of Florence one, and that of Rome another? Epistle 1i, 2. Trans. Milino 653, 65.1 )

50 Votwithstanding the somewhat "Joftier" tone of the Comirio, especially when compared with the lita Nuora, it is nonetheless mostly concerned with "eathly" matters. For example, Comitio I. ii deals extensively with the debate as to the merits of the vernacular whereas in Paradiso. we see that, ultimately. spoken language is of litale use in explaining the divine mysteries. Though Dante enjoins God to grant him the power to speak of the marvels he saw ("O) isplendor di Dio, per cu io vidi lalto triunfo del regno) verace. dammi virtú a dir com io il vicli!" Par: 30, 9-- 99) such entreaties are ultimately unanswered for earthly language is inadequate for the task of describing divine truth. ("Da quinci innanzi il mio vecler fu maggio/ che I parlar mostra, ch'a tal vista cede, e cede la memoria a tanto oltraggio." P(17: 33, 55-57.)

Similarly, in the Combicio H, iii, Dante discusses the placement of the celestial spheres and the inhabitants of hearen yet in the Paradiso, the placement of the blessed is revealed to be little more than a representation for the benefit of those without divine vision. " Qui si mostraro, non perché sortita' sia questa spera lor, ma per far segno/ de la spiritual cha men salita. Cosi parlar conviensi al vostro ingegno, però che solo da sensato apprende ciò che fa poscia d'intelletto degno. Per questo la Scrittura condescencle a vostra facultate, e piedi e mano attribuisce a Dio, e altro intende;" Par: i, 37-45.)

51 "E che ciò sia, per due apertissime ragioni veder si può, le quali mostrano quella città essere imperadrice, e da Dio avere speziali nascimento, e da Dio avere spezial processo." (Conl'. IV, iv)

52 "Ná siccome ciascuna arte e ufficio umano dallo imperiale è a certi termini limitato: così questo imperio da Dio a certi termini è finito." (Come. IV, ix)

53 "che 'l giardin de lo "mpero sia diserto." (Purg. 6, 105)

54 "cuti sarai tu poco tempo silvano; e sarai meco sanza fine cive di quella Roma onde Cristo è romano." (Purg. 32. 100-102)

55 This is not a connection made only by Dante. The connection between earthly and spiritual pilgrimage was so strong in the Middle Ages, according to Debra Birch, that for ordinary men and women "travelling to the earthly Jenusalem seemed little different to travelling to the heavenly one and pilgrimage came to be popularly regarded as a way of achieving salvation and getting to heaven." (2) Rome enjoyed equal popularity as a pilgrimage site and accordingly, the connection between Rome and Jersualem was informed by the connection made between Jerusalem and heaven. That earthly places such as cities could not only share meaning $m$ ith each other and with their spiritual allegorical counterparts was typical of medieval thought patterns. As Sabine MacCormack points out, in mediateval thought "the symbol and the prototype were regarded as equal, or at least part of the same reality:" (7)

56 "dove l'acqua del Tevero s'insala." (Purg. 2, 101)

57 "Poi seguitai lo "imperador Currado; ed el mi cinse de la sua milizia, tanto per bene ovrar li venni in grado./ Dietro li andai incontro a la nequizia di quella legge il cui il popolo usurpa per colpa d'i pastor, vostra giustizia. Quivi fu' io cla quella gente turpa disvillupato dal mondo fallace, to cui amor moltanime deturpa; $;$ e venni dal martiro a questa pace." (Par: 15, 142-148)

58 "Lo principe d'i novi Farisei, avendo guerra presso a Laterano, e non con Saracin né con Giudei, ché ciascun suo nimico era Cristiano, e nessun era stato a vincer Acri né mercatante in terra di Soldano." (Inf. $2^{-}, 85-90$ )

59 "Oh quali io vidi quei che son disfatti per lor superbia!" (Par. 16, 109-110)

60 "e le palle de l'oro. fiorian Fiorenza in tutt'i suoi gran fatti." (Par: 16, 110-111)

61 "Gradually the idea hegan to form that the Middle Ages might think of figures of virtues and vices as memory images, formed according to the classical rules, or the clivi- 
sions of Dante's Hell as memory places." (xii) "That Dante's Inferno could be regarded as a kind of memory system for memorizing Hell and its punishments with striking images on orders of places will come as a great shock. It would take a whole book to work out the implications of such an approach to Dante's poem. It is by no means a crude approach, nor an impossible one. If one thinks of the poen as based on orders of places in which the spheres of Hell are the spheres of Heaven in reverse, it begins to appear as a summa of similitudes and exempla, ranged in order and set out upon the universe." (96)

62 Amilcare Iannucci notes that "no single source can account for Dante's representation of paradise as a rose" but, based in part on Giuseppe Di Scipio's position, Iannucci theorizes that it "may have been suggested to him by the lofty rose windows of medieval cathedrals or the roselike depictions of heaven in early Italian art." ("Paradiso XXXI" 472) See also Di Scipio, Giuseppe C. The Symbolic Rose in Dante's Paradiso. Ravenna: Longo, 1984.

\section{WORKS CITED}

Alighieri, Dante. Il Conito di Dante Alighieri e le epistole. Ed. Pietro Fraticelli. Florence: Barbèra, 1887.

La Divina Commedia. Ed. Natalino Sapegno. Milan: Ricciardi, 1955.

La Divina Commedia. 3 vols. Ed. Natalino Sapegno. Florence: La Nuova

Italia Editrice, 1985.

La Vita moza. Ed. Domenico De Robertis, Milan: Ricciardi, 1984.

Auerbach, Erich. Studi su Dante. Milan: Feltrinelli, 1966. Mimesis. Princeton: Princeton UP, 1968.

Barolini, Theodolinda. The Undivine Comedy: Detheologizing Dante. Princeton: Princeton UP, 1992.

Birch, Debra J. Pilgrimage to Rome in the Middle Ages. Continuity and Change. Woodbridge: Boydell Press, 1998.

Bolzoni, Lina. "Costruire immagini. L'arte della memoria tra letteratura e arti figurative." La cultura della memoria. Bologna: Mulino, 1992. 57-97.

Carruthers, Mary J. The Book of Memomy. A Study of Memory in Medieval Culture. Cambridge: Cámbridge UP, 1990.

Charity, Alan C. Euents and their Afterlife. Cambridge: Cambridge UP, 1966.

D'Entrèves, A.P. Dante as a Political Thinker. Oxford: Clatendon Press, 1952.

Farrnell, S. The Political Ideas of the Divine Comedy: An Introduction. Lanhan: UP of America, 1985.

Ferrante, Joan M. The Political Vision of the Divine Comedy. Princeton: Princeton UP, 1984.

Di Scipio, Giuseppe C. The Symbolic Rose in Dante's Paradiso. Ravenna: Longo, 1984. Hollander, Robert. Studies in Daute. Ravenna: Longo, 1980.

Holmes, Urban Tigner. Chrétien De Troyes. New York: Twayne, 1970.

Iannucci, Amilcare A. Forma ed eiento nella Divina Commedia. Rome: Bulzoni, 1984. "Paradiso XXXI." Lectura Damtis 16-17 (Spring-Fall 1995). Special Issue.

Lectura Dantis Virginiana, Vol. 11I. Dante's Dizine Comedy. Introductory Readings III: Paradiso. Ed. Tibor Wlassics. 470-485.

"Forbidden Love: Metaphor and History (Infermo 5)." Dante: Contemporary Perspectices. Ed. Amilcare A. Iannucci. Toronto: U of Toronto P, 1997. 94-112. 
Kleiner, John. Mismapping the L'ndertorkl. Daring and Error in Dante's 'Comedy' Stanforct: stanford UP, 1994.

Leo, Ulrich. "The Unfinished Comitio and Dante's Rereading of the Aeneid." Mediacval Studies 13 (1951): 11-61.

MacCormack, Sabine. "Loca Sancta: The Organization of Sacred Topography in Late Antiquity". The Blessings of Pilgrimage. Robert Ousterhoust, Ed. Urbana: It of Hlinois P, 1990. 7-40.

Milano, Patolo, ed. The Portable Dante. New York: Viking Press, 1947.

Nardi, Bruno. Dal "Convivio" alla "Commedia" (Sei saggi danteschi). Rome: Istituto Storico Italiano per il Medio Evo, 1992.

Petrocchi, Giorgio. Biografia. Attizità politica e letterearie. Vol. 6 of Enciclopedia Dantesca. Rome, 1978.

Piattoli, R. Codice diplomatico dantesco. Florence, 1950.

Singleton, Charles, S. Dante Studies 2: The Journey to Beatrice. Cambridge: Harvard U.P., 1967.

Yates, Frances A. The Ant of Memory. Chicago: U of Chicago I', 1966.

Virgil. The Aeneid. Trans. WW.F. Jackson Knight. London: Penguin, 1958. 